\title{
Mebulle Bai: \\ Ritual, Ruang Bersama, dan Rekonsiliasi Masyarakat Lokal di Mamasa, Sulawesi Barat
}

\author{
Stepanus \\ Universitas Kristen Satya Wacana - Salatiga \\ 752017009@student.uksw.edu \\ Izak Y.M. Lattu \\ Universitas Kristen Satya Wacana - Salatiga \\ lattu@staff.uksw.edu \\ Tony Tampake \\ Universitas Kristen Satya Wacana \\ tampake@staff.uksw.edu
}

\begin{abstract}
The establishment of Mamasa as a district adds diversity and escalation of conflict which often occur not only in the form of fights or physical clashes, but also of differences in perception. This situation is exacerbated by the governance of conflict which tends to use judicial or repressive approach. An approach that only pays attention to rules and punishments without trying to build sustainable peaceful relations in society. The research objective to be achieved in this paper is to describe and analyze the Mebulle Bai Ritual as a shared space in solving the social conflict of the Mamasa community. The implementation of the Mebulle Bai Ritual is a symbolic act intended to restore the relations of various parties in the conflict. Restoring relationships in conflict is aimed at resolving the conflict as well as all parties, such as family and society. This approach is based on a common understanding that conflict could break relation of the conflicting parties and contribute to destroy harmony in society. Therefore, recovery is a comprehensive process supported by the presence of various
\end{abstract}


parties in building peace. The result achieved is the Mebulle Bai ritual which can be ruled as a shared space in resolving conflicts because they contain the values of justice, equality and humility. Each party is equally enforced, regardless of their religious, ethnic, cultural, racial and social status in society.

[Terbentuknya Mamasa sebagai kabupaten menambah kemajemukan dan eskalasi konflik. Konflik terjadi bukan hanya dalam bentuk perkelahian atau benturan secara fisik, tetapi juga karena perbedaan persepsi. Situasi ini diperparah oleh tata kelola konflik yang cenderung menggunakan pendekatan lembaga kepolisian dan peradilan. Pendekatan yang hanya memberi perhatian pada aturan dan hukuman, tanpa berusaha membangun relasi damai yang berkelanjutan dalam masyarakat. Adapun tujuan penelitian yang hendak dicapai dalam tulisan ini adalah mendeskripsikan dan menganalisis Ritual Mebulle Bai sebagai ruang bersama penyelesaian konflik sosial masyarakat Mamasa. Pelaksanaan Ritual Mebulle Bai merupakan tindakan simbolis yang dimaksudkan untuk memulihkan hubungan berbagai pihak dalam konflik. Pemulihan hubungan dalam konflik bukan hanya tertuju bagi mereka yang berkonflik, tetapi mencakup semua pihak seperti keluarga dan masyarakat. $\mathrm{Hal}$ ini didasarkan pada pemahaman bahwa konflik bukan hanya merusak relasi pihak yang berkonflik tetapi sesungguhnya ikut merusak harmoni dalam masyarakat. Karena itu pemulihan yang dilakukan adalah pemulihan yang menyeluruh. Hal ini ditandai dengan kehadiran berbagai pihak dalam membangun perdamaian. Hasil yang dicapai adalah Ritual Mebulle Bai yang dapat menjadi ruang bersama dalam penyelesaian konflik karena mengandung nilai keadilan, kesetaraan dan kerendahan hati. Setiap pihak diberlakukan secara sama, tanpa memandang latar belakang agama, suku, budaya, ras, dan status sosial dalam masyarakat.]

Keywords: Ritual, shared space, social conflict.

\section{Pendahuluan}

Artikel ini membahas ritual mebulle bai sebagai ruang bersama penyelesaian konflik sosial masyarakat Mamasa. Ritual adat yang secara turun temurun diyakini dan terbukti sebagai sarana yang dapat 
mempertemukan berbagai pihak untuk membicarakan konflik secara damai. Perdamaian dibangun berdasar pada falsafah ada' tuo, ${ }^{1}$ yakni penyelesaian masalah yang mengedepankan nilai-nilai kemanusiaan, seperti keadilan dan kesetaraan. Konflik dibicarakan melalui musyawarah mufakat dengan melibatkan berbagai pihak, seperti tokoh adat, tokoh agama, pemerintah, keluarga dan pihak yang berkonflik. Hasilnya adalah semua pihak dipulihkan dan membangun damai yang berkelanjutan dalam masyarakat. Bentuk pemulihan seperti ini, terkadang tidak dijumpai dalam proses perdamaian yang dilakukan melalui lembaga kepolisian dan peradilan. Perdamaian yang dibangun melalui lembaga formal terkadang hanya bersifat sementara, yang kemudian menyimpan sejumlah dendam dan permusuhan berkelanjutan dalam masyarakat. Dengan demikian, tindakan Ritual Mebulle Bai sebagai kearifan lokal masyarakat Mamasa, mestinya dikaji lebih dalam sebagai salah satu alternatif untuk membangun perdamain yang memulihkan, berkelanjutan dan bukannya hukuman

Sejauh ini, kajian tentang ritual adat Mamasa masih sangat minim. Beberapa penelitian tentang adat dan ritual tetapi lebih pada ritual berburu kepala, ritual naik pohon baranak, ritual kesuburan, ritual kelahiran, ritual pernikahan dan ritual kematian. ${ }^{2}$ Penelitian lain dilakukan oleh Aguswati Hildebrandt Rambe, Secara khusus menguraikan ritual kematian dan kedukaan di Mamasa. ${ }^{3}$ Penelitian khusus tentang adat Mamasa dilakukan oleh Rambalangi, tetapi sebatas mengkaji fungsi lembaga adat dalam pembangunan Kecamatan Tawalian Kabupaten Mamasa. ${ }^{4}$ Setelah memeriksa berbagai tulisan tentang budaya dan ritual di Mamasa, penulis tidak menemukan penjelasan secara terperinci tentang ritual adat yang digunakan dalam membangun perdamaian. Selain itu, studi tentang ritual

\footnotetext{
${ }^{1}$ Ada' berarti aturan atau kepercayaan yang harus ditaati. Sementara Tuo berarti hidup. Secara sederhana $A d a^{\prime}$ Tuo berarti aturan hidup yang memberi perhatian pada nilai-nilai kehidupan dalam masyarakat.

${ }^{2}$ Kees Buijs, Agama Pribadi dan Magi di Mamasa, Sulawesi Barat: Mencari Kuasa Berkat dan Dunia Dewa-dewa (Makassar: Ininnawa, 2017), 75-121.

3 Aguswati Hildebrandt Rambe, Keterjalinan dalam Keterpisahan: Mengupayakan Teologi Interkultural dari Kekayaan Simbol Ritus Kematian dan Kedudukan di Sumba dan Mamasa (Makassar: Yayasan Oase INTIM, 2014).

4 Rambalangi, "Eksistensi Lembaga Adat dalam Pembangunan Kecamatan Tawalian Kabupaten Mamasa: Suatu Studi di Kecamatan Tawalian Kabupaten Mamasa Provinsi Sulawesi Barat," Jurnal Ekesekutif, Vol. 1 No. 1, 2018.
} 
telah dilakukan oleh beberapa sosiolog antropolog seperti Victor Turner, ${ }^{5}$ Catherine Bell, ${ }^{6}$ melihat ritual sebagai penguatan ikatan tradsi sosial dan individu dengan struktur sosial dari kelompok. Integrasi dikuatkan melalui simbolisme ritual. Jadi ritual dipahami sebagai perwujudan esensial kebudayaan.

Studi tentang ritual dalam hubungannya dengan perdamaian masih sangat terbatas. Ada studi tentang ritual dalam hubungannya dengan membangun perdamaian, akan tetapi hanya sebatas bagaimana ritual dapat digunakan dalam membangun perdamaian. Karena itu, tulisan ini akan menggali lebih dalam tentang ritual sebagai ruang bersama penyelesaian masalah atau konflik. Teori Lisa Schrich tentang ritual dan simbol akan membantu penulis dalam melihat ritual mebulle bai sebagai tindakan simbolis penyelesaian konflik di Mamasa. Sementara pendalaman terhadap ritual sebagai ruang bersama, menggunakan buku Jeffrey Alexander tentang the civil Sphere.

Alexander mengungkapkan ruang sipil sebagai lingkup solidaritas. Ia mengatakan bahwa masyarakat tidak diperintah oleh kekuatan dan pengejaran pribadi, ${ }^{7}$ tetapi lebih pada solidaritas dalam perasaan terhubung dengan orang lain. Solidaritas yang memberi penghormatan terhadap hakhak individu dan kewajiban kolektif dalam masyarakat. Masyarakat sipil dipahami sebagai suatu lingkup solidaritas, dimana suatu jenis komunitas universal tertentu secara kultural terdefenisi dan pada tingkat tertentu secara institusional dipaksakan. ${ }^{8}$ Bagi Alexander, solidaritas hanya mungkin terjadi jika kesadaran sosial dan kewajiban individu terhubung secara baik.

Jenis penelitian yang digunakan adalah penelitian deskriptif dengan metode kualitatif. Penelitian dilakukan di wilayah sekitar ibu kota Kabupaten Mamasa, yakni wilayah pemerintahan Kecamatan Mamasa. Data diperoleh melalui metode observasi tanpa ikut berpartisipasi (nonparticipant observation), wawancara, dan analisis. Wawancara dilakukan secara

\footnotetext{
5 Victor Turner, The Ritual Process: Structure and Anti-Structure (New York: Cornel University Press, 1969), 19.

${ }^{6}$ Catherine Bell, Ritual Theory, Ritual Practice (New York: Oxford University Press, 1992) 67, 220.

${ }^{7}$ Jeffrey Alexander, The Civil Sphere, (New York: Oxford University Press, 2006), 3.

${ }^{8}$ Ibid., 31.
} 
face-to-face interview (wawancara berhadap-hadapan) melaui sejumlah pertanyaan yang bersifat terbuka. " Wawancara dilakukan terhadap sejumlah informan seperti tokoh adat, tokoh masyarakat, pemerintah desa dan pelaku ritual. Para tokoh adat adalah sejumlah orang yang memiliki pengetahuan dan pengalaman yang cukup tentang pelaksanaan Ritual Mebulle Bai. Mereka selalu terlibat langsung dalam berbagai penyelesaian masalah atau konflik secara adat.

Selain wawancara, penulis juga melakukan studi dokumenter dan studi pustaka dengan menggunakan foto-foto ritual dan buku-buku yang terkait dengan pokok penelitian. Studi ini dilakukan guna memperoleh informasi dan landasan teori dalam memahami pokok penelitian. Data yang diperoleh dianalisis melalui beberapa langkah, yakni reduksi data, penyajian data, dan kesimpulan. ${ }^{10}$ Reduksi data yang dimaksud adalah menggolongkan dan memilih data yang penting untuk memberikan gambaran yang jelas tentang pokok penelitian. Kemudian data yang direduksi, disajikan dalam bentuk uraian singkat dan dibangun dalam hubungan dengan yang lain. Terakhir, kesimpulan sebagai hasil analisis data yang diperoleh melalui penelitian kualitatif. Dengan demikian, tulisan ini berkesimpulan bahwa Ritual Mebulle Bai, sebagai salah satu kearifan lokal masyarakat Mamasa, memiliki makna sosial yang dapat membangun relasi kemanusiaan. Makna sosial yang dimaksud adalah keadilan, kesetaraan dan kerendahan hati.

\section{Budaya dan Relasi Sosial Masyarakat Mamasa}

Mamasa merupakan salah satu kabupaten yang berada di wilayah pegunungan Provinsi Sulawesi Barat, yang awalnya biasa disebut TorajaBarat. ${ }^{11}$ Mamasa terbentuk sebagai satu kabupaten pada tanggal 11 Maret 2002, sesuai dengan Undang-undang Nomor 11 tahun 2002 tentang

\footnotetext{
9 John W Creswell, Research Design: Pendekatan Kwalitatif, Kwantitatif, dan Mixed (Yogyakarta: Pustaka Pelajar, 2016), 254.

10 Sugiyono, Memahami Penelitian Kwalitatif (Bandung: Alfabeta, 2012), 343-345.

${ }^{11}$ Selain letaknya yang berada di sebelah Barat Kabupaten Tana Toraja, dalam sejarahnya asal usul orang Mamasa dari bulu sa'dan (Tana Toraja). Secara adat, budaya dan bahasa memiliki kemiripan dengan orang-orang yang ada di Toraja. Sisi lain, terdapat perbedaan sehingga orang-orang Mamasa terkadang lebih senang menyebut dirinya dengan To Mamasa (orang Mamasa).
} 
pembentukan Kabupaten Mamasa dan kota Palopo. Pada awal terbentuknya Kabupaten Mamasa masuk dalam wilayah Provinsi Sulawesi Selatan. Dua tahun kemudian, dengan terbitnya Undang-undang Nomor 26 tahun 2004 tentang pembentukan Provinsi Sulawesi Barat, Kabupaten Mamasa masuk dalam wilayah Provinsi Sulawesi Barat bersama dengan empat kabupaten lainnya yaitu Kabupaten Majene, Kabupaten Polewali Mandar, Kabupaten Mamuju, dan Kabupaten Mamuju Utara.

Masyarakat Mamasa merupakan masyarakat adat yang masih mempertahankan berbagai tradisi dalam menata kehidupan sosial masyarakat. Tradisi adat dipahami sebagai aturan sakral yang harus dipatuhi. ${ }^{12}$ Sakralitas adat dilatarbelakangi oleh mitologi asal usul tatanan kehidupan manusia di Mamasa. Orang Mamasa meyakini bahwa adat berasal dari dewa di langit yang diturunkan kepada manusia untuk ditaati. ${ }^{13}$ Aturan adat diturunkan melalui dewa di langit yang disebut dengan tomanurun, yakni dewa yang turun dari langit. ${ }^{14}$ Ketaatan terhadap aturan akan mendatangkan kesejahteraan, sementara pelanggaran mengakibatkan hukuman.

Peraturan adat yang mengatur kehidupan manusia di bumi disebut dengan istilah pemali appa' randanna, berarti empat dasar hidup, yakni: (1) pa'bannetauan mengatur tentang ritus atau upacara perkawinan dan kelahiran, (2) Pa'bisuan mengatur hubungan manusia dan ilahi melalui ibadah, seperti ibadah syukuran karena keberhasilan, (3) Pa'totiboyongan merupakan aturan atau upacara ritual yang dilakukan kepada dewata totiboyong (dewa padi atau pertanian). ${ }^{15}$ (4) Pa'tomatean, mengatur tentang ritual kematian.

Keempat aturan di atas, dapat dibagi dalam dua bagian besar, yakni ritual kehidupan yang biasa disebut Rambu Tuka' dan ritual kematian yang

\footnotetext{
12 Mauruds Genggong, sebagai tokoh adat Tawalian, Wawancara mendalam, Tatale, 20 Agustus 2018.

13 Demmaroa, sebagai budayawan masyarakat Mamasa, Wawancara mendalam, Lemba Banggo, 23 Agustus 2018.

${ }^{14}$ Kees Buijs, Kuasa Berkat dari Belantara dan Langit: Struktur dan Transformasi Agama Orang Toraja di Mamasa Sulawesi Barat (Makassar: Ininnawa, 2009), 14-70.

15 Arianus Mandadung, Keunikan Budaya Pitu Ulunna Salu Kondosapata Mamasa (Mamasa: 2005), 51.
} 
biasa disebut sebagai Rambu Solo, ${ }^{16}$ Pembagian aluk ini dilatarbelakangi oleh kosmologi orang Mamasa yang membedakan arah mata angin baik melalui terbit dan terbenamnya matahari maupun melalui aliran sungai terutama aliran sungai Mamasa. ${ }^{17}$ Arah hulu sungai diartikan arah atas sebagai tempat dewa yang memberi kehidupan, sementara arah hilir merupakan dunia bawah sebagai tempat air mengalir dan matahari terbenam yang dihubungkan dengan dunia kematian.

Selain beberapa sistem sosial religius di atas, terdapat empat sistem sosial yang mengatur tentang stratifikasi sosial dalam masyarakat. Keempat strata sosial yang dimaksud dikenal dengan sebutan tana ${ }^{18}$ Pertama, tana' bulawan yakni tau tongan atau para bangsawan. ${ }^{19}$ Kedua, tana' bassi yang merupakan bagian dari golongan bangsawan biasa. Disebut sebagai bagian dari golongan bangsawan karena ikut membantu hadat dalam memerintah masyarakat. ${ }^{20}$ Menurut penuturan Maurids Genggong, tana' bassi masuk dalam golongan orang kaya dan tua-tua kampung. ${ }^{21}$ Ketiga, tana' karurung, yakni golongan masyarakat biasa atau merdeka. Mereka bukan pemimpin dan bukan hamba dalam masyarakat. Mereka adalah masyarakat biasa yang bersifat independen. ${ }^{22}$ Keempat, tana' koa-koa, golongan hamba. W.A.Van der Klis dalam buku Datanglah Kerajaan-Mu.., membagi dua golongan hamba. Pertama disebut sabua' garonto (hamba tunggal pohon), yakni mereka menjadi hamba sejak lahirnya karena nenek moyang mereka sejak

\footnotetext{
16 Secara harfiah Rambu Tuka' berarti asap yang membubung ke atas, sementara Rambu Solo' berarti asap yang ke bawah. Kees Buijs dalam buku Agama Pribadi dan Magi di Mamasa, Sulawesi Barat: Mencari Kuasa Berkat dari Dunia Dewa-dewa menghubungkan Rambu Tuka' dan Rambu Solo' dengan dapur sebagai tempat orang Mamasa membangun relasi dengan dewata.

17 Aguswati Hildebrandt Rambe, Keterjalinan dalam Keterpisahan, 70.

18 Secara harfiah tana' berarti pancang atau batang yang biasa digunakan untuk menentukan batas tanah. Jadi tana adalah batas antara seseorang dengan yang lain berupa strata sosial dalam masyarakat.

${ }^{19}$ Maurid Genggong sebagai tokoh adat Tawalian Wawancara mendalam, Tatale, 20 Agustus 2018. Demmaroa' sebagai budayawan Mamasa, Wawancara mendalam, Lemba Banggo, 23 Agustus 2018.

20 Van der Klis, Datanglab Kerajaan-Mu: Lima Pulub Tabun Pekabaran Injil di Toraja Barat 1913-1963 (Rantepao: Sulo, 2007), 16.

${ }^{21}$ Maurids Genggong sebagai tokoh adat tawalian, wawancara mendalam, Tatale, 20 Agustus 2018.

22 Arianus Mandadung, Keunikan Budaya, 116.
} 
dulu sebagai hamba. Kedua, mereka menjadi hamba karena situasi tertentu, misalnya karena ditangkap pada waktu perang (todirapa) atau karena tidak mampu membayar utang. ${ }^{23}$ Hal ini dipertegas oleh bp. Maurids Genggong, dengan mengatakan bahwa golongan hamba yang kedua ini dimasukkan dalam salah satu tana' yakni tana' daun dambu, golongan budak belian, orang-orang yang dibeli, yang " dicabut hak kemanusiaannya". ${ }^{24}$

Sistem adat yang dikembangkan dalam masyarakat Mamasa adalah sistem adat yang bersifat demokratis. Hal ini diwujudkan dalam satu semboyan sitayuk, sikamase, sirande maya-maya, berarti 'saling menghargai, saling mengasihi dan saling mendukung.' Hal ini terwujud dalam berbagai relasi kemanusiaan, seperti dalam acara rambu tuka dan rambu solo'. Nilainilai luhur seperti gotong royong dan sistem kekeluargaan masih sangat kuat ditemukan dalam masyarakat Mamasa. Secara khusus dalam mekanisme penyelesaian konflik, hubungan kekeluargaan menjadi salah satu pertimbangan dalam pengambilan keputusan.

\section{Sejarah dan Mekanisme Penyelesaian Konflik: Ritual Mebulle Bai}

Ritual perdamaian adat masyarakat Mamasa muncul sebagai reaksi terhadap fenomena sosial yang terjadi di tengah-tengah masyarakat. Fenomena sosial yang dimaksud adalah bias interpretasi terhadap sistem Ada' Mate, ${ }^{25}$ yakni sistem yang mengedepankan nilai-nilai siri' (harga diri) dan eksistensi diri. Siri' berarti rasa malu yang terjadi karena suatu peristiwa di dalam masyarakat. Peristiwa tersebut dapat berupa cacian, fitnah yang kemudian berakibat pada konflik. Karena seseorang mengalami rasa malu dalam peristiwa tersebut, maka harga dirinya harus dipulihkan sesuai dengan perasaan atau korban yang terjadi. Sistem ini mengedepankan

\footnotetext{
${ }^{23}$ Van der Klis, Datanglah Kerajaan-Mu, 17.

${ }^{24}$ Maurids Genggong, salah seorang tokoh adat tawalian, wawancara mendalam, Tatale, 20 Agustus 2018.

${ }_{25}$ Ada' mate adalah salah satu aturan kehidupan masyarakat yang dilakukan berdasar pada prinsip “Pampuli Tedong paottong karambu”, berarti seseorang yang melakukan pelanggaran di dalam masyarakat akan dihukum setimpal dengan perbuatannya. Prinsipnya ialah suatu perbuatan dalam masyarakat harus dihukum sesuai dengan perbuatannya, tidak ada sistem pengampunan.
} 
sistem balas dendam dalam masyarakat yang secara keseluruhan disebut dengan sistem Ada' Mate.

Sistem Ada' Mate didasarkan pada prinsip 'Pampuli Tedong Paottong Karambu', artinya seseorang yang melakukan pelanggaran dihukum setimpal dengan perbuatannya. ${ }^{26}$ Sistem ini tidak mengenal adanya pengampunan, sebab seseorang yang melakukan kesalahan seperti membunuh ia pun harus dibunuh. Paham rela mati dalam menegakkan siri' atau harga diri dianggap sebagai suatu tindakan ksatria. ${ }^{27}$ Istilah tobarani ${ }^{28}$ merupakan salah satu istilah yang populer bagi seseorang yang berhasil mengorbankan orang lain melalui pembunuhan.

Kenyataan sosial seperti ini, mendapat tindakan evaluatif dari para tokoh adat, secara khusus Nenek Tomampu'. ${ }^{29}$ Demmaroa' sebagai salah seorang budayawan Mamasa mengatakan bahwa kenyataan sosial masyarakat Mamasa pernah mengalami degradasi, yakni munculnya sistem balas dendam yang kemudian dipulihkan oleh seorang yang bernama To' mampu' ${ }^{30}$ Nenek Tomampu' mengusulkan supaya sistem Ada' Mate ditinjau kembali, sebab masyarakat saling dendam dan terancam punah melalui tindakan saling membunuh. Usul ini disambut baik oleh para tokoh adat lainnya, kemudian melakukan pertemuan untuk musyawarah mufakat. Pertemuan tersebut dilaksanakan di lantang kada nenek ${ }^{31}$ melalui suatu

\footnotetext{
26 Tiboyong sebagai tokoh Masyarakat Mamasa, wawancara mendalam, Buntu Buda, 29 Oktober 2018.

27 Demmaroa' sebagai budayawan Mamasa, wawancara mendalam, Lemba Banggo, 23 Agustus 2018.

${ }_{28}$ To artinya orang, sementara barani berarti berani. Secara harfiah tobarani berarti orang pemberani, menunjuk pada seseorang yang dapat berhasil mengalahkan lawan dengan mengorbankan lawan melalui pembunuhan.

29 Tomampu' berarti Londong Dewata, yakni utusan Tuhan dari Waka' Pana' (wilayah Kecamatan Pana') yang berdiam di Rantebulahan.

30 Dammaroa' sebagai salah seorang sejarawan Mamasa, wawancara mendalam, Lemba Banggo, 23 Agustus 2018. Timotius Tiboyong, sebagai tokoh masyarakat, Wawancara mendalam Buntu buda, 29 Oktober 2018.

${ }^{31}$ Lantang Kada Nenek merupakan gelar keadatan yang menunjuk pada tempat para toko adat melakukan musyawarah dari berbagai wilayah kehadapat di Pitu Ulunna Salu. Tempat musyawarah ini berada di Mambi, yakni salah satu wilayah kecamatan di Pemerintahan Kabupaten Mamasa.
} 
keputusan yang disebut dengan 'randangan puduk papparan lila' artinya keputusan yang diambil secara musyawarah mufakat.

Pertemuan para tokoh adat menyepakati bahwa hukum Ada' Mate dengan prinsip 'pampuli tedong paottong karambu' dihapuskan dan diganti dengan bentuk hukum adat yakni Ada' Tuo dengan prinsip Dikondo Tedong Ditampa Bulawan atau Tuo Tammate Mapia Tangkadake yang berarti persoalan apa pun yang terjadi, selalu ada jalan untuk menyelesaikan secara baik dan damai. Sejak itu, semua bentuk persoalan yang terjadi di Mamasa selalu diupayakan diselesaikan secara baik dan damai. Penyelesaian masalah yang terjadi umumnya dilakukan dalam bentuk ritual melalui tindakan simbolis, tindakan yang mengandung nilai-nilai kemanusiaan, yakni mempersatukan, memperdamaikan dan memperbaharui relasi dalam masyarakat. Adapun mekanisme ritual adalah sebagai berikut:

1. Mediasi: Pelaksanaan ritual perdamaian adat masyarakat Mamasa diawali dengan proses mediasi oleh para tokoh adat. Pola mediasi yang dilakukan adalah dengan cara mediator menjadi penengah bagi pihak yang sedang berkonflik, dimana mereka yang sedang berkonflik tidak berkomunikasi langsung, tetapi melalui mediator. Tokoh adat akan mendatangi rumah pihak yang berkonflik untuk memperoleh informasi tentang konflik dan memberi penyadaran akan pentingnya membangun perdamaian di dalam masyarakat. Marthen Arruan Silomba sebagai pemerintah desa Osango, mengatakan bahwa pihak yang berkonflik dalam masyarakat dimediasi dengan maksud supaya masalah atau konflik yang terjadi dapat diperkecil untuk membangun perdamaian bagi semua pihak. ${ }^{32}$

2. Prosesi Ritual: Hasil mediasi yang dilakukan parah tokoh adat, ditindaklanjuti dalam tindakan ritual Mebulle Bai. Pihak yang dianggap bersalah dalam konflik akan diantar oleh keluarga yang dituakan untuk membangun perdamaian di tempat yang ditentukan. Beberapa orang berjalan di depan memikul atau membawa babi. Babi yang dipikul mendahului rombongan keluarga dengan maksud supaya setiap pihak, khususnya pihak yang dirugikan dalam konflik dapat membuka diri untuk

32 Marthen Arruan Silomba, sebagai pemerintah Desa Osango, wawancara mendalam, Osango 31 Oktober 2018. 
menerima pihak lain dalam membangun perdamaian. Setelah mereka sampai, babi diletakkan di pintu rumah, sementara keluarga dan pihak yang bersalah akan masuk ke dalam rumah untuk membicarakan konflik secara damai.

3. Musyawarah untuk Mufakat: Musyawarah dibangun berdasar pada prinsip $A d a^{\prime}$ Tuo yakni keputusan ditetapkan secara bersama dan diterima oleh semua pihak yang hadir. Maurids Genggong mengatakan bahwa satusatunya pertimbangan dalam mencari solusi perdamaian adalah tidak boleh memberatkan pihak lain. ${ }^{33}$ Tokoh adat sebagai pihak ketiga harus mampu bersifat netral dan mengutamakan prinsip saling menguntungkan. Prinsip ini menegaskan bahwa penyelesaian konflik melalui musyawarah merupakan sebuah upaya damai yang dilakukan dengan tidak mengorbankan satu pihak, tatapi memberi kelegaan dan kepuasan dalam melanjutkan damai dalam masyarakat.

4. Berjabat Tangan dan Berdoa: Setelah musyawarah mufakat, perdamaian dilanjutkan dengan tindakan berjabat tangan dan berdoa bersama. Berjabat tangan merupakan tanda bahwa berbagai pihak telah saling memaafkan dan saling menerima. Sementara berdoa dimaknai sebagai wujud syukur atas penyertaan Tuhan selama konflik. Sekaligus permohonan berkat untuk menyatakan damai secara berkelanjutan dalam masyarakat.

5. Makan Bersama: Makan bersama merupakan bagian akhir proses perdamaian yang dilakukan. Makan bersama diartikan sebagai sarana untuk mengintegrasikan hubungan yang tegang karena konflik, berubah menjadi relasi damai yang berkelanjutan dalam masyarakat. Bagi masyarakat Mamasa makan bersama dipahami sebagai sarana untuk memperkuat hubungan kekeluargaan dalam masyarakat. ${ }^{34}$ Makan bersama menjadi tanda bahwa perdamaian yang dibangun telah diterima semua pihak dan memberi kelegaan.

\footnotetext{
33 Maurids Genggong, sebagai tokoh adat Tawalian, wawancara mendalam, Tatale, 20 Agustus 2018.

${ }^{34}$ Demmaroa' sebagai budayawan Mamasa, wawancara mendalam, Lemba Banggo 23 Agustus 2018.
} 


\section{Ritual Mebulle Bai sebagai Ruang Bersama Penyelesaian Konflik}

Ritual Mebulle Bai merupakan salah satu bentuk penyelesaian konflik yang membuka ruang bagi semua pihak untuk menyelesaikan masalahnya secara damai. Setiap pihak yang hadir dalam tindakan ritual berpartisipasi aktif mencari solusi yang dapat diterima semua pihak untuk membangun perdamaian yang berkelanjutan dalam masyarakat. Pihak yang berkonflik akan diberlakukan secara sama tanpa memandang latar belakang tertentu dalam masyarakat, seperti agama, suku, ras, budaya, dan status sosial. Menurut penuturan Maurids Genggong, bahwa sebagai jiwa dari falsafah $A d a^{\prime}$ Tuo maka dalam proses penyelesaian masalah atau konflik semua orang dipandang secara sama. ${ }^{35}$

Perlakuan secara sama bagi semua pihak, dilandasi oleh kesadaran bersama akan pentingnya membangun perdamaian atas setiap konflik yang terjadi. Kesadaran berbagai pihak dalam membangun perdamaian merupakan kekuatan utama dalam membangun hubungan yang baik dalam masyarakat. Hubungan-hubungan sosial dalam masyarakat hanya akan terjalin dengan baik jika solidaritas sosial menjadi kekuatan komunitas. Hal inilah yang disebutkan Alexander sebagai civil sphere atau ruang yang terbangun karena solidaritas kolektif orang dalam masyarakat. ${ }^{36}$ Bahwa di dalam setiap komunitas masyarakat selalu ada kesadaran bersama untuk membangun masyarakat ke arah yang lebih baik. Sehingga persoalan apa pun yang terjadi, selalu ada upaya untuk mencari solusi dari persoalan tersebut. Dengan demikian, solidaritas menjadi kunci utama dalam membangun masyarakat yang damai.

Ritual Mebulle Bai dilaksanakan sebagai bentuk solidaritas semua pihak untuk membangun perdamaian. Alexander memperlihatkan bahwa di dalam masyarakat sipil ada solidaritas yang muncul bukan karena kepentingan diri sendiri atau hubungan kekuasaan tetapi perasaan moral yang universalitas untuk orang lain. ${ }^{37}$ Perasaan bagi orang lain inilah yang memungkinkan terciptanya kesadaran untuk membangun perdamaian. Kesadaran untuk berdamai melekat dalam diri seseorang yang didorong oleh berbagai tindakan yang dapat mempertemukan dan mempersatukan

\footnotetext{
${ }^{35}$ Mauruds Genggong, tokoh adat Tawalian, wawancara mendalam, Tatale, 20 Agustus 2018. ${ }^{36}$ Jeffrey Alexander, The Civil Sphere, 31.

${ }^{37}$ Ibid., 33.
} 
pihak yang berkonflik. Secara khusus dalam Ritual Mebulle Bai peranan pihak ketiga sangat menentukan munculnya kesadaran berbagai pihak untuk berdamai.

Ritual Mebulle Bai membuka ruang yang mendorong penghormatan terhadap yang lain. Ia menjadi ruang bersama karena membuka ruang bagi semua budaya, agama, gender dan kelas untuk diterima dalam sebuah ruang solidaritas bersama. Alexander mengatakan bahwa hanya solidaritas yang bersifat universal, perasaan terhubung dengan orang lain yang dapat menyatukan individu dari berbagai kelas, ras, agama, dan etnis. ${ }^{38}$ Karena kekuatan solidaritas, maka ruang sipil menerobos segala batas-batas yang ada, termasuk batas geografis. Ritual menjadi kekuatan bersama untuk menghormati hak mereka yang berbeda, membangun kepercayaan sosial dan menjadikan kehendak baik sebagai motivasi dan tujuan berelasi dengan orang lain. Dengan demikian, ritual Mebulle Bai disebut sebagai ruang bersama karena:

\section{Partisipasi aktif setiap pihak}

Partisipasi setiap pihak merupakan dasar membangun perdamaian. Semua peserta musyawarah dalam tindakan ritual Mebulle Bai berperan aktif dalam mencari solusi yang terbaik dari konflik yang terjadi dalam masyarakat. Pembicaraan tentang konflik dan solusinya dilakukan secara terbuka dan demokratis. Alexander mengatakan bahwa kita perlu mengembangkan modal masyarakat demokratis yang lebih memperhatikan perasaan bersama dan komitmen simbolis, untuk apa dan bagaimana orang berbicara, berpikir dan merasa tentang politik dan lebih umum tentang kehidupan sosial yang demokratis. ${ }^{39}$ Solidaritas sosial dalam ritual Mebulle Bai nampak pada tindakan responsif pihak yang berkonflik untuk membangun perdamaian. Perasaan untuk ingin membangun hubungan dengan orang lain dalam tindakan simbolis merupakan bentuk solidaritas yang bersifat universal dalam membangun hubungan yang lebih baik dalam masyarakat.

\footnotetext{
${ }^{38}$ Ibid., 43.

${ }^{39}$ Ibid.
} 


\section{Penghormatan terhadap Hak Individu}

Setiap individu yang terlibat dalam konflik akan diproses sesuai dengan sistem adat yang berlaku. Sistem yang memberi perhatian besar terhadap nilai-nilai kemanusiaan. Alexander mengatakan bahwa hanya ruang sipil yang dapat mengatur kekuatan dan menghilangkan kekerasan sewenang-wenang. ${ }^{40}$ Ruang yang terbangun melalui tindakan ritual Mebulle Bai terbukti mampu mempertemukan setiap pihak untuk menyelesaikan konflik secara damai. Setiap kesalahan yang terjadi tidak dibalas sesuai dengan pelanggarannya, melainkan diupayakan diproses secara damai melalui tindakan ritual Mebulle Bai. Binatang sebagai korban dianggap sebagai pengganti kesalahan. Sehingga siapa pun yang berkonflik akan diberlakukan secara sama tanpa memandang latar belakang tertentu dalam masyarakat, seperti agama, suku, budaya dan status sosial.

\section{Perdamaian dibangun secara Kolektif}

Perdamaian yang dibangun di dalam tindakan ritual Mebulle Bai adalah perdamaian yang bersifat kolektif. Perdamaian yang dibangun secara bersama-sama dan memulihkan berbagai hubungan dalam konflik. Keputusan yang diambil bersifat demokratis yang dapat memberi kepuasan bagi semua pihak. Tidak ada satu pihak yang diuntungkan atau monopoli pembicaraan dalam proses musyawarah. Alexander mengatakan bahwa ketika dominasi satu lingkup atas wilayah lain atau monopoli sumber daya oleh para elit telah diblokir, maka ranah sipil sebagai ruang bersama telah dialami oleh masyarakat. ${ }^{41}$ Dengan demikian, penyelesaian konflik melalui tindakan ritual Mebulle Bai merupakan kekayaan masyarakat yang telah berhasil memberi penghargaan terhadap hak-hak individual dalam masyarakat. Universalitas solidaritas telah terbangun dalam upaya membangun perdamaian yang dapat diterima oleh semua pihak dan memberi kelegaan untuk melanjutkan perdamaian di dalam masyarakat. Lebih jauh Alexander mengatakan bahwa solidaritas hanya bersifat sipil jika menggabungkan kolektif dengan kewajiban individu. ${ }^{42}$

\footnotetext{
40 Ibid., 552.

${ }^{41}$ Ibid., 33.

42 Ibid., 38.
} 


\section{Ritual Mebulle Bai dalam Makna Keadilan, Kesetaraan dan Keren- dahan Hati}

Berdasarkan pelaksanaan tradisi adat Ritual Mebulle Bai di Mamasa, ada beberapa makna yang ditemukan dalam membangun relasi kemanusiaan, yakni nilai keadilan, kesetaraan, dan kerendahan hati. Schrich dalam bukunya, Ritual and Symbol in peacebuliding, mengatakan bahwa cara untuk merangkul dimensi simbolis peacebuilding adalah mengenali efek mendalam yang dimiliki oleh tindakan simbolis terhadap kemanusiaan'. ${ }^{43}$ Ketiga nilai yang dimaksud, terjalin secara kuat dalam prinsip dan pelaksanaan ritual Mebulle Bai. Karena itu, ketiga makna tersebut akan diuraikan secara terpisah seperti di bawah ini.

\section{a. Keadilan dalam Mebulle Bai}

Keadilan merupakan harapan bersama yang mengandung nilai kebenaran untuk diwujudkan dalam setiap proses penyelesaian masalah atau konflik. Kamus Besar Bahasa Indonesia (KBBI) mengartikan adil, 'tidak berat sebelah, tidak memihak dan tidak sewenang-wenang.' Pengertian ini memperlihatkan bahwa dalam hal menyatakan keadilan, kebenaran harus menjadi prioritas utama dalam proses penyelesaian masalah atau konflik dalam masyarakat. John Rawls dalam bukunya, $A$ Theory of Justice, mengemukakan dua prinsip keadilan: ${ }^{44}$ (1) setiap orang memiliki hak yang setara atas kebebasan; dan (2) ketidaksetaraan di bidang ekonomi dan sosial harus diatur sehingga kedua-duanya menjadi keuntungan bagi setiap orang, dan melekat pada kedudukan yang terbuka bagi setiap orang. Kedua prinsip keadilan di atas memberi penekanan pada keadilan kesetaraan. Kebebasan harus diberikan secara setara kepada semua orang karena di dalam masyarakat yang adil semua warga memiliki hak dasar yang sama.

Pendapat lain dikemukakan oleh Alexander dengan mengatakan bahwa keadilan tergantung pada solidaritas, pada perasaan terhubung dengan orang lain, menjadi bagian dari sesuatu yang lebih besar dari diri kita sendiri, keseluruhan yang membedakan kewajiban dan memungkinkan kita untuk berbagi, perasaan dan kognisi, memberi kita kesepakatan untuk

${ }^{43}$ Lisa Schrich, Ritual and Simbol in Peacebuilding (Amerika: Kumarin Press, 2005), 4.

${ }^{44}$ John Rawls, A Theory of Justice (Combridge, Mass: Harvard University Press, 1971), 52. 
partisipasi yang berarti, dan menghormati kepribadian individu bahkan sambil memberi kita perasaan bahwa kita semua berada di perahu yang sama. ${ }^{45}$ Keadilan dipandang sebagai kebutuhan dalam sebuah komunitas, dimana di dalamnya tercipta hidup saling menghormati satu dengan yang lain.

Keadilan sebagai sebuah kebutuhan tidak hanya ditemukan dalam peradilan formal, seperti lembaga kepolisian dan peradilan. Nilai keadilan dapat ditemukan dalam budaya masyarakat, yang dipedomani secara turun temurun dalam menata kehidupan masyarakat yang harmonis. Penataan terhadap kehidupan masyarakat diwujudkan dalam berbagai situasi dan tempat tertentu. Bagi masyarakat Mamasa, keadilan dapat ditemukan dalam ritual adat Mebulle Bai sebagai upaya membangun perdamaian dari setiap masalah atau konflik yang terjadi. Nilai keadilan yang terdapat dalam pelaksanaan ritual Mebulle Bai, ditemukan dalam mekanisme penyelesaian konflik yang mengedepankan pemulihan relasi damai berbagai pihak; pihak yang berkonflik, keluarga dan masyarakat. Bentuk keadilan seperti ini masuk dalam kategori keadilan restoratif, yakni keadilan yang bersifat memulihkan, dan bukan menghukum.

Yoachim Agus Tridiatno mengartikan keadilan restoratif sebagai bentuk keadilan yang berpusat pada kebutuhan korban, pelaku kejahatan dan masyarakat. ${ }^{46}$ Pengertian ini kemudian dikembangkan dalam tiga prinsip dasar keadilan restoratif. Pertama, keadilan restoratif mengutamakan pemulihan atau restorasi bagi semua pihak yang terkena dampak dari tindak kejahatan, yaitu korban, pelaku, dan masyarakat. Kedua, berkaitan dengan cita-cita pemulihan (restorasi) di atas, keadilan restoratif fokus pada kebutuhan tiga pihak, yakni korban, pelaku kejahatan, dan masyarakat yang tidak dipenuhi oleh proses peradilan. Ketiga, keadilan restoratif memperlihatkan kewajiban dan tanggung jawab yang muncul oleh karena tindakan kejahatan. Pelaku kejahatan wajib memulihkan kerusakan yang diderita korban, dan masyarakat.

Ketiga prinsip di atas memperlihatkan bahwa keadilan restoratif berpusat pada pemulihan dan pendamaian kembali korban, pelaku

\footnotetext{
45 Jeffrey Alexander, The Civil Sphere, 13.

${ }^{46}$ Yoachim Agus Tridianto, Keadilan Restoratif (Yogyakarta: Cahaya Atma Pustaka, 2015), 27.
} 
kejahatan, dan masyarakat. Pemulihan korban, pelaku kejahatan dan masyarakat merupakan fokus utama dalam keadilan restoratif. Pemulihan itu diwujudkan dalam sebuah tanggung jawab atas peristiwa konflik yang terjadi. Konflik dipahami bukan hanya persoalan kedua belah pihak, tetapi peristiwa konflik merupakan tanggung jawab bersama yang harus diselesaikan secara damai dan bermartabat. Dalam buku Restorative Justice: How it Works Mariam Leibmann dengan rinci mengemukakan beberapa prinsip restorarive justive, ${ }^{47}$ yakni: (1) victim support and healing is a priority (dukungan dan pemulihan korban merupakan prioritas), (2) offenders take responsibility for what they have done (pelanggar bertanggung jawab atas apa yang telah mereka lakukan), (3) there is dialogue to achieve understanding (ada dialog untuk mencapai kesepahaman), (4) there is an attempt to put right the harm done (ada upaya untuk mengganti kerugian dengan tepat), (5) offenders look at how to avoid future offending (pelanggar melihat bagaimana masa depan untuk menghindari penyesalan/rasa bersalah), (6) the community helps to reintegrate both victim and offender (masayarakat membantu untuk mengintegrasikan kembali antara korban dan pelaku).

Prinsip keadilan restoratif di atas memperlihatkan perhatian yang besar terhadap pemulihan relasi dalam konflik. Pihak yang dirugikan dalam konflik akan dipulihkan melalui pengakuan dan permohonan maaf pihak yang bersalah. Sementara perdamaian dibangun dalam musyawarah mufakat yang melibatkan berbagai pihak. Hasilnya adalah relasi damai terbangun bukan hanya kedua belah pihak tetapi terbangun secara bersama-sama sebagai satu komunitas sosial.

Prinsip keadilan restoratif yang diuraikan di atas, sejalan dengan nilai keadilan yang terdapat dalam mekanisme pelaksanaan Ritual Mebulle Bai. Pelaksanaan Ritual Mebulle Bai mengedepankan pemulihan relasi kemanusiaan dalam konflik. Nilai ini diuraikan dalam beberapa pokok, yakni:

\section{Pemulihan Relasi dalam Konflik}

Ritual Mebulle Bai dilaksanakan dalam rangka memulihkan hubungan yang rusak oleh karena konflik. Hubungan yang dipulihkan

\footnotetext{
${ }^{47}$ Mariam Leibmann, Restorative Justice: How it Works (London: Jessica Kingsley Publisher, 2007), 26-27.
} 
bukan hanya bagi pihak yang sedang berkonflik, tetapi hubungan yang melibatkan keluarga dan masyarakat. Kehadiran berbagai pihak dalam pelaksanaan ritual menunjukkan bahwa relasi damai yang terbangun adalah relasi yang mencakup berbagai pihak, yakni pemulihan pihak yang berkonflik, keluarga dan masyarakat. Bagi masyarakat Mamasa, sistem kekeluargaan sangat kental dan dijunjung tinggi dalam kehidupan bermasyarakat. Setiap peristiwa konflik yang terjadi dianggap merusak harmoni dalam keluarga dan masyarakat. Sehingga dalam pelaksanaan Ritual Mebulle Bai juga dipahami sebagai upaya untuk memulihkan relasi kekeluargaan yang rusak karena konflik.

Pemulihan relasi dalam tindakan Ritual Mebulle Bai pertama-tama ditujukan pada relasi antara pihak yang berkonflik. Pihak yang dirugikan dalam konflik, dianggap sebagai pihak yang paling merasakan penderitaan fisik dan mental. Karena itu, dengan tindakan Ritual Mebulle Bai oleh pihak yang dianggap bersalah dalam konflik, dimaksudkan sebagai bentuk pemulihan harkat dan martabat pihak yang dikorbankan. Menurut David, Ritual Mebule Bai merupakan salah satu bentuk pemulihan harkat dan martabat bagi pihak yang dikorbankan dalam konflik. ${ }^{48}$

Selain pemulihan bagi pihak yang dikorbankan dalam peristiwa konflik, sesungguhnya dalam Ritual Mebulle Bai juga sedang terjadi pemulihan bagi pihak yang dianggap bersalah dalam konflik. Pemulihan itu diwujudkan dalam sebuah kesadaran tanggung jawab akan kesalahan yang terjadi dalam konflik. Pengakuan dan permohonan maaf yang diungkapkan dalam tindakan ritual merupakan suatu proses penting di dalam penyembuhan luka-luka batin dan penderitaan yang dialami oleh pihak yang bersalah. Tanggung jawab dan pengakuan pihak yang bersalah dalam konflik terjadi karena ada komunikasi yang terbangun dan komunikasi itu berawal dari tindakan ritual. Penerimaan kembali melalui komunikasi yang baik dalam proses penyelesaian masalah merupakan bentuk pemulihan yang terjadi bagi pihak yang dianggap bersalah dalam konflik.

Fungsi relasional dari pelaksanaan Ritual Mebulle Bai sangat mendalam. Ritual Mebulle Bai dapat memberi dampak yang luas dan luar

${ }^{48}$ David, tokoh adat Rambusaratu', wawancara mendalam, Rambusaratu’ 18 Agustus 2018. 
biasa pada kualitas hubungan yang baik antara pihak yang berkonflik, keluarga dan tokoh adat yang memfasilitasi pertemuan adat. Ritual berfungsi baik sebagai sosialisasi dan transformasi. Kedua kekuatan ini menjalin hubungan koreografi, kadang-kadang bertindak sebagai pelumas sosial dan terkadang sebagai jalur perubahan. Ritual bersosialisasi ketika membangun, melindungi, mempertahankan dan mendukung pola dan struktur relasional yang ada dalam suatu komunitas. ${ }^{49}$ Bagi Schirch, ritual berubah ketika ia membantu mengubah suatu hubungan dari satu cara berprilaku, pola interaksi, atau struktur sosial yang lain.

\section{Musyawarah dan Dialog}

Dalam Ritual Mebulle Bai terbangun ruang bagi semua pihak untuk melakukan musyawarah, membangun perdamaian. Musyawarah perdamaian melibatkan pihak yang berkonflik, tokoh adat, tokoh agama, pemerintah dan keluarga. Kehadiran berbagai pihak dimaksudkan untuk memulihkan hubungan yang rusak karena konflik menjadi hubungan yang baik dan harmonis. Semua pihak terlibat aktif dalam membicarakan konflik dan solusinya. Tokoh adat sebagai mediator perdamaian akan membuka musyawarah dan memberi kesempatan berbagai pihak untuk berbicara. Pihak yang dirugikan dalam konflik akan menyampaikan perasaan batin yang terjadi akibat konflik untuk didengarkan oleh semua pihak. Pihak yang bersalah dalam konflik akan mendengar dan menyampaikan perasaannya tentang konflik untuk menyampaikan permohonan maaf yang tulus bagi semua pihak atas konflik yang terjadi.

Di dalam musyawarah akan terjadi dialog antar berbagai pihak yang dapat memberikan kepuasan tersendiri dalam penyelesaian konflik. Kebutuhan akan informasi atau jawaban atas berbagai pergumulan dalam konflik akan terjawab dengan baik melalui musyawarah dan dialog berbagai pihak, khususnya pihak yang berkonflik. Penyembuhan luka batin dapat terjadi ketika setiap pihak diberi kesempatan untuk menyampaikan penderitaan yang dialami karena konflik. Sikap saling menerima dan menghargai akan tercipta dalam proses dialog, sehingga perdamaian akan terbangun secara baik dan benar.

${ }^{49}$ Lisa Schrich, Ritual and Simbol, 38. 
Akhirnya pihak yang hadir dalam musyawarah akan mendengar dan memberi petuah, serta solusi untuk membangun perdamaian. Pemulihan berbagai pihak terjadi dalam bentuk musyawarah dan dialog. Budaya musyawarah, sebagai sistem nilai yang dihayati oleh masyarakat Mamasa, merupakan semangat untuk masing-masing pihak yang berunding di dalam musyawarah tersebut untuk menyelesaikan konflik, akan berupaya mengurangi pendiriannya sehingga dapat dicapai titik temu yang menguntungkan bagi semua pihak, yang berujung pada mufakat.

\section{Keadilan untuk semua pihak}

Dengan musyawarah untuk mencapai mufakat semua pihak akan mendapat tempat yang sama dalam konflik. Setiap pihak diberi kesempatan untuk mengungkapkan isi hatinya sehubungan dengan konflik. Mereka akan didengar dan dihormati dalam pertemuan, sebagai ruang untuk saling memberi, saling menerima dan saling memaafkan melalui peristiwa konflik. Di dalam pertemuan akan terjadi dialog sebagai gambaran terciptanya keadilan restoratif. Dialog yang dibangun bertujuan untuk mencari solusi bersama untuk meletakkan tanggung jawab yang tepat atas tindakan seseorang dalam konflik. Musyawarah akan berakhir dengan perdamaian, semua pihak akan puas menerima berbagai keputusan. Perdamaian terbangun sebagai tanggung jawab bersama. Demikianlah keadilan restoratif terwujud ketika perdamaian dan rekonsiliasi antara korban, pelaku, dan masyarakat keluarga terwujud serta dipulihkan.

Keadilan restorarif dapat menjamin kesejahteraan bersama, karena berakhir dengan proses damai, bukan dendam dan kebencian. Hal ini berbeda dengan proses peradilan melalui lembaga kepolisian yang terkadang mengakibatkan hukuman dan permusuhan yang berkepanjangan. Pemulihan harkat dan martabat kemanusiaan secara menyeluruh menjadi kepuasan dari semua pihak untuk melanjutkan perdamaian. Mereka akan hidup damai karena hak-hak mereka telah terpenuhi melalui proses musyawarah dan dialog yang mengungkapkan dan mendengarkan perasaan batin bagi pihak-pihak yang berkonflik. Hal 
ini akan membawa kelegaan bagi semua pihak dan merasa puas dengan proses perdamaian yang terbangun.

Dengan demikian jelas bahwa dalam Ritual Mebulle Bai, pemulihan harkat dan martabat menyangkut harga diri pihak yang dirugikan dalam konflik sangat dijunjung tinggi. Nilai keadilan restoratif tampak dalam seluruh mekanisme yang dilakukan dalam proses perdamaian. Semua pihak akan mengalami kedamaian yang sejati sebab terjadi pemulihan relasi yang dapat berkelanjutan dalam kehidupan masyarakat. Setiap pihak yang hadir dalam tindakan ritual akan merasa lega dan bertanggung jawab dalam menghadirkan kedamaian yang berkelanjutan dalam berbagai relasi sosial dalam masyarakat.

\section{b. Kesetaraan dalam Mebulle Bai}

Tradisi adat Ritual Mebulle Bai merupakan bagian integral dari tatanan kehidupan sosial masyarakat Mamasa. Sistem kasta yang berakar dalam masyarakat Mamasa ternyata tidak menjadi ukuran atau syarat pelaksanaan Ritual Mebulle Bai. Berdasarkan hasil penelitian yang dilakukan penulis, beberapa informan yang memahami tentang adat Ritual Mebulle Bai umumnya menuturkan bahwa strata sosial atau kasta dalam masyarakat tidak menjadi ukuran atau penghalang dalam melakukan tindakan Ritual Mebulle Bai. Bagi mereka Ritual Mebulle Bai merupakan tindakan simbolis untuk membangun perdamaian yang didasarkan pada falsafah $A d a^{\prime}$ Tuo dimana setiap orang dipandang secara sama di dalam proses penyelesaian masalah atau konflik. Setiap orang atau kelompok yang hadir dalam konflik diberlakukan secara sama tanpa memandang latar belakang tertentu. Tindakan Ritual Mebulle Bai memberi penghormatan yang sama bagi setiap pihak yang hadir dalam proses penyelesaian masalah atau konflik. Masyarakat yang terstruktur dengan sistem kasta yang ketat, dipertemukan dalam ruang bersama untuk membicarakan masalah-masalah kehidupan, yakni membangun relasi damai yang berkelanjutan dalam masyarakat.

Pelaksanaan Ritual Mebulle Bai memberi makna bahwa masyarakat dibebaskan dari hegemoni yang terstruktur dalam masyarakat. Penghormatan terhadap individu melalui perasaan terhadap yang lain merupakan karakter civil sphere yang diungkapkan oleh Alexander. Ruang solider muncul bukan melalui kepentingan pribadi atau hubungan 
kekuasaan dan status sosial dalam masyarakat, melainkan ruang solider muncul sebagai bentuk perasaan moral bagi orang lain untuk membangun relasi yang lebih baik dalam berbagai masalah atau konflik yang terjadi. Bagi Alexander, perasaan moral seperti inilah yang menjadi eksistensi masyarakat sipil. Dominasi satu lingkup atas yang lain telah disingkirkan untuk membangun hubungan sipil yang lebih demokratis.

Menurut David, seorang tokoh adat, dalam Ritual Mebulle Bai ada aspek kesetaraan di mana semua manusia dianggap secara sama. ${ }^{50}$ Ritual ini menciptakan sebuah model untuk bagaimana hubungan dengan orang lain, peserta menyatukan niat konstruktif mereka untuk berinteraksi dengan orang lain dalam hubungan yang setara dan saling menghormati. Tidak ada yang dianggap lebih dari yang lain; semua orang diberi kesempatan untuk terlibat dalam komunikasi. Singkatnya, latar belakang yang berbeda, seperti agama, suku, budaya dan status sosial dalam masyarakat, tidak menjadi penghalang dalam membangun perdamaian.

\section{c. Kerendahan Hati dalam Mebulle Bai}

Pelaksanaan ritual melalui tindakan simbolis terjadi karena ada kesediaan bagi pihak yang berkonflik untuk saling memaafkan dan saling menerima satu dengan yang lain. Permohonan maaf dinyatakan dalam tindakan simbolis dan tindakan tersebut mengandung arti bahwa pihak yang dianggap bersalah dalam konflik telah insaf, menyesali kesalahannya dan siap untuk membangun hubungan damai dengan yang lain. Sebaliknya, bagi pihak yang dirugikan dalam konflik, membuka diri dan menerima kehadiran pihak lain untuk membangun perdamaian. Ritual Mebulle Bai terjadi karena pihak yang berkonflik memiliki kerendahan hati seorang terhadap yang lain. Kerendahan hati menjadi pintu masuk bagi para mediator yakni tokoh adat untuk membangun perdamaian melalui proses mediasi.

Ketiga makna sosial di atas memperlihatkan bahwa Ritual Mebulle Bai dapat menjadi ruang bersama bagi semua pihak untuk mewujudkan solidaritas kemanusiaan, seperti keadilan, kesetaraan, dan kerendahan hati. Penghormatan terhadap hak dan kewajiban setiap individu dalam proses

${ }^{50}$ David, tokoh adat Rambusatau', wawancara mendalam, Rambusaratu’ 18 Agustus 2018. 
penyelesaian masalah merupakan hakikat dari masyarakat sipil. Ritual Mebulle Bai telah menjadi ruang bersama bagi semua pihak tanpa memandang agama, budaya, ras dan status sosial dalam masyarakat. Ritual Mebulle Bai telah menjadi kekuatan bersama untuk menghormati hak mereka yang berbeda, dan membangun kepercayaan sosial dan menjadikan kehendak baik sebagai motivasi atau tujuan relasi dengan orang lain.

\section{Kesimpulan}

Ritual merupakan bagian esensial dalam kehidupan manusia. Di satu sisi ia mengikat secara bersama, dan di sisi lain menjelma sebagai alat untuk membangun atau mentransformasi hubungan. Menurut Schrich, berpartisipasi dalam ritual membantu orang mengalami rasa kesehatan, keutuhan dan kekudusan yang lebih lengkap. Setiap agama menggunakan ritual untuk memperkuat hubungan baik antara manusia dan Tuhan dan di antara pengikut agama manusia. Ritual tidak hanya terbatas pada fungsi relasional religius tetapi juga dalam membangun solidaritas sosial dengan semua pihak.

Ritual Mebulle Bai merupakan salah satu tradisi adat masyarakat Mamasa yang hingga kini masih digunakan dalam proses penyelesaian masalah atau konflik dalam masyarakat. Tradisi adat yang dilakukan berdasar pada falsafah $A d a^{\prime}$ 'Tuo, yakni upaya damai yang dilakukan tanpa mengorbankan seseorang atau masyarakat. Upaya damai tersebut dilakukan dengan melibatkan berbagai pihak dengan cara musyawarah untuk mufakat. Keterlibatan berbagai pihak seperti tokoh adat, tokoh agama, pemerintah dan keluarga dalam membangun perdamaian merupakan bukti nyata bahwa kedamaian merupakan cita-cita bersama yang perlu diperjuangkan dalam masyarakat. Bagi masyarakat Mamasa kedamaian merupakan salah satu tujuan hidup yang harus diusahakan, selain secara individual juga secara bersama-sama.

Pelaksanaan Ritual Mebulle Bai merupakan tindakan simbolis yang dimaksudkan untuk memulihkan hubungan berbagai pihak dalam konflik. Pemulihan hubungan dalam konflik bukan hanya tertuju bagi mereka yang berkonflik, tetapi mencakup semua pihak seperti keluarga dan masyarakat. Hal ini didasarkan pada pemahaman bahwa konflik bukan hanya merusak relasi pihak yang berkonflik tetapi sesungguhnya ikut merusak harmoni 
dalam masyarakat. Karena itu pemulihan yang dilakukan adalah pemulihan yang secara menyeluruh. Hal ini ditandai dengan kehadiran berbagai pihak dalam membangun perdamaian.

Perdamaian yang dibangun melalui tindakan Ritual Mebulle Bai mengandung berbagai makna: makna keadilan, kesetaraan dan kerendahan hati. Makna keadilan terwujud dalam tindakan simbolis yang dilakukan oleh pihak yang dianggap bersalah dalam konflik, sementara pihak yang dirugikan akan membuka diri dan menerima tindakan simbolis itu sebagai bentuk perdamaian kedua belah pihak. Nilai kesetaraan terwujud ketika setiap orang dipandang dan diberlakukan secara sama dalam konflik tanpa memandang latar belakang agama, budaya, ras, dan status sosial dalam masyarakat. Sementara nilai kerendahan hati terwujud melalui kesediaan untuk membangun perdamaian dengan cara saling menerima dan saling mengakui antara pihak yang berkonflik.

\section{DAFTAR PUSTAKA}

\section{Buku dan Jurnal}

Jeffrey, Alexander. The Civil Sphere. New York: Oxford University Press, 2006.

Bell, Catherine. Ritual Theory, Ritual Practice. New York: Oxford University Press, 1992.

Bell, Catherine. Ritual: Perspective and Dimension. New York: Oxford University Press, 1997.

Cassier, Ernst. An Essay on Man. New York: Yale University Press, 1944. Chinwokwu. "Community Based Early Warning in Conflict Management and Peace Building in Nigeria: An Analysis of Internal Security Issues," Journal of Culture, Society and Development, Vol. 9. 2015.

Cooley, Frank L. Mimbar dan Takhta: Hubungan Lembaga-lembaga Keagamaan dan Pemerintah di Maluku. Jakarta: Pustaka Sinar Harapan, 1987.

Creswell, John,W. Research Design: Pendekatan Metode Kwalitatif, Kuantitatif dan Campuran. Yogyakarta: Pustaka Pelajar, 2017.

Darlis. Konflik Komunal: Studi dan Rekonsiliasi Konslik Poso. Yogyakarta: Litera, 2012. 
Deutsch, Morton, Colemen, Peter T, dan Marcus, Eric C. Handbook Resolusi Konflik: Teori dan Praktek. Bandung: Nusa Media, 2016.

Dhavamony, Mariasusai. Fenomenologi Agama. Yogyakarta: Kanisius, 2003.

Dillistone, F.W. The Power of Symbols. Yogyakarta: Kanisius, 2002.

Durkheim, Emile. The Elementary Forms of Religious Life. America: The Free Press, 1995.

Firth, Raymond. Symbols: Public and Private. Allen and Unwin, 1973.

Geertz, Clifford. Kebudayaan dan Agama. Yogyakarta: Kanisius, 1992.

Ichsan, Malik. Resolusi Konflik: Jembatan Perdamaian. Jakarta: Kompas Media Nusantara, 2017.

Katz, Jonathan G. Architecture as Symbol and Self-Identity. Philadelphia: Aga Khan Awards, 1990.

Kees, Buijs. Agama Pribadi dan Magi di Mamasa Sulawesi Barat: Mencari Kuasa Berkat dari Dunia dewa-dewa. Makassar: Innawa, 2017.

Kees, Buijs. Kuasa Berkat Dari Belantara dan Langit: Struktur dan Transformasi Agama Orang Toraja di Mamasa Sulawesi Barat. Makassar: Ininnawa, 2009.

Kees, Buijs. Tradisi Purba Rumah Toraja Mamasa Sulawesi Barat: Banua sebagai Pusat Kuasa Berkat. Makassar: Ininnawa, 2018.

Klis, W.A. Van der. Datanglah Kerajaan-Mu: Lima Pulub Tabun Pekabaran Injil di Toraja Barat 1913- 1963. Rantepao: Sulo, 2007.

Leibmann, Leibmann. Restorative Justice: How it Works. London: Jessica Kingsley Publischer, 2007.

Mandadung, Arianus. Keunikan Budaya: Pitu Ulunna Salu Kondosapata Mamasa. Mamasa, 2005.

Moelong, Lexy J. Metodologi Penelitian Kualitatif. Bandung: PT. Remaja Rosda, 1994.

Pruitt, Dean G. dan Rubin, Jeffrey Z. Teori Konflik Sosial. Yogyakarta: Pustaka pelajar, 2011.

Rambalangi. "Eksistensi Lembaga Adat dalam Pembangunan Kecamatan Tawalian Kabupaten Mamasa: Suatu Studi di Kecamatan Tawalian Kabupaten Mamasa Provinsi Sulawesi Barat. Jurnal Eksekutif, Vol. 1 No. 1. 2018. 
Rambe, Aguswati Hildebradt. Keterjalinan dalam Keterpisahan: Mengupayakan Teologi Interkultural dari Kekayaan Simbol Ritus Kematian dan

Kedukaan di Sumba dan di Mamasa. Makassar: Yayasan Oase INTIM, 2014.

Rappaport, Roy A. Ritual and Religion in the Making of Humanity. United Kingdom: Cambridge University Press, 1999.

Rawls, John. A Theory of Justice. Cambridge, Mass: Harvard University Press, 1971.

Rawls, John. Teori Keadilan: Dasar-Dasar Filsafat Politik Untuk Mewnjudkan Kesejabteraan Sosial dalam Negara. Yogyakarta: Pusataka Pelajar, 2011.

Schrich, Lisa. Ritual and Simbol In Peacebuilding. Amerika: Kumarin Press,2005.

Singgih, Emanuel Gerrit. Korban dan Pendamaian: Studi Lintas Ilmu, Lintas Budaya, dan Lintas Agama Mengenai Upaya Manusia Menghadapi Tantangan Terbadap Kebidupan di Luar endalinya. Jakarta: BPK Gunung Mulia, 2017.

Sugiyono. Memahami Penelitian Kwalitatif. Bandung: Alfabeta, 2012.

Susan, Novri. Negara Gagal Mengelola Konflik: Demokrasi dan Tata Kelola Konflik di Indonesia. Yogyakarta: Pustaka Pelajar, 2012.

Susan, Novri. Pengantar Sosiologi Konflik. Jakarta: Prenadamedia Group, 2009.

Turner, Victor W. 1996, The Ritual Process: Structure and Anti-Structure. New York: Cornel University Press, 1996.

Winangun, Y.W. Masyarakat Bebas Struktur: Liminalitas dan Komunitas Menurut Victor Turner. Yogyakarta: Kanisius, 1990.

Yoachim, Agus Tridiatno. Keadilan Restoratif. Yogyakarta: Cahaya Atma Pustaka, 2015.

Yusak, Setyawan B.(dkk). Perdamaian dan Keadilan: Dalam Konteks Indonesia yang Multikultural dan Beragam tradisi Iman. Jakarta: BPK Gunung Mulia, 2017. 


\section{Wawancara}

Wawancara dengan A. Demmasa'bu, sebagai salah seorang tokoh adat 'Tokeran sepu' di Osango, 4 Januari 2018

Wawancara dengan. Benyamin Matasak, salab seorang tokoh adat Sesena Padang, 6 Januari 2018.

Wawancara dengan Yuliadi Ma'dika, salah seorang tokoh adat 'Tokeran sepu' 8 Januari 2018.

Wawancara dengan Bongga Baranak, salah seorang tokoh adat Rambusatu', 15 Agustus 2018.

Wawancara dengan Obed Nego Depparinding, sebagai ketua Aliansi Masyarakat Adat Nusantara (AMAN) Mamasa, 16 Agustus 2018

Wawancara dengan David, sebagai salah seorang tokoh adat Rambusaratu', 18 Agustus 2018

Wawancara dengan Sarah Sambolayuk, salah seorang tokoh adat Sesena Padang, 19 Agustus 2018

Wawancara dengan Maoroids Genggong, salah seorang tokoh adat Tawalian, 20 Agustus 2018

Wawancara dengan Matasak, salah seorang tokoh adat Sesena Padang, 21 Agustus 2018

Wawancara dengan Demmaroa, seorang budayawan Mamasa, 23 Agustus 2018

Wawancara dengan Paulus Bosong, pada tanggal 25 Oktober 2018 di Mamasa.

Wawancara dengan Timotius Tiboyong sebagai tokoh masyarakat pada tanggal 29 Oktober 2018 di Buntu Buda.

Wawancara dengan Marthen Arruan Silomba sebagai pemerintah desa Osango pada tanggal 31 Oktober 2018. 